\title{
引張荷重下における三次元接合体角部の 特異応力場内の微小き裂の応力解析
}

\section{Stress analysis near a small crack within singular stress field in a three-dimensional bonded joint under a tensile load}

\author{
Hideo KOGUCHI ${ }^{* 1}$ and Naoki KIMURA ${ }^{* 2}$ \\ ${ }^{* 1}$ Dept. of Mechanical Engineering, Nagaoka University of Technology \\ 1603-1 Kamitomioka-cho, Nagaoka-shi, Niigata 940-2188, Japan \\ ${ }^{* 2}$ Nippon Steel \& Sumitomo Metal Co. \\ 1 Kimitsu, Kimitsu-shi, Chiba 299-1141, Japan
}

\section{Received 18 April 2014}

\begin{abstract}
Stress singularity usually occurs at a vertex of interface in a three-dimensional joint. Crack frequently initiates at a vertex and a joint fails under an external force and a thermal load. In the present paper, stress distribution near a small crack occurring at a vertex in a three-dimensional joint is investigated under a tensile load, and stress intensity factor at the crack tip are determined along the crack tip front. The joint is composed of Si and resin. In the analysis, three kinds of crack shape, triangular, quarter circular and concave shapes, are supposed as an initial crack shape. Stresses are normalized using the singular stress around the vertex since the crack exists in the stress singular field. The stress intensity factor in the quarter circular crack increases and that in the others decreases as approaching side surfaces. The quantity of energy release due to a crack initiation is calculated using relative displacements of the crack and the stress distribution of singular stress field. The quantity for the concave shape crack is the largest in the three kinds of crack shape.
\end{abstract}

Key words : Stress singularity, Interface, Delamination, Fracture mechanics, Energy release rate, Three-dimensional joints

\section{1. 緒言}

特性の異なる材料が接合された異材接合体には，その材料特性の違いから界面端に特異応力場が発生する.こ の接合体に外力あるいは温度変動を与えると，特異応力場により接合界面端に界面き裂あるいは界面近傍にき裂

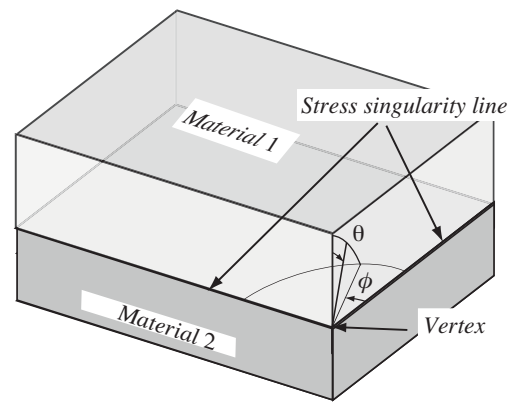

Fig.1 Three-dimensional bonded structures

No.14-00220 [DOI: 10.1299/transjsme.2014smm0220]

*1 正員，フェロー，長岡技術科学大学（广940-2188＼cjkstart新潟県長岡市上富岡町 1603-1）

*2 新日鉄住金(株)（宁299-1141 千葉県君津市君津 1 番地）

E-mail of corresponding author: koguchi@mech.nagaokaut.ac.jp 
が発生し，接合体の強度低下を引き起こすことがある（結城，1993）。Williams(1959)は界面き裂を持つ弾性体の 㛜密解を求め, 応力場の振動特異性について言及した. その後, Erdogan (1965), Rice と Shih(1965)および Rice(1988) が界面き裂先端の応力と変位の解を示している. Hutchinson と Suo (1991)は複素応力拡大係数の実部と虚部は通 常き裂のモード I と II に対応することを指摘した. 界面端の特異応力場内に発生する微小き裂の応力拡大係数の 評価は, 実際の接合体強度を調べる上で重要である. 井岡ら(井岡他, 2002)は二次元接合体界面近傍に微小なき 裂が存在する場合の解析を行い，き裂先端に及ぼす特異応力場の影響を調べている．また，Akisanya ら(Akisanya and Fleck, 1997)は二次元接合体の界面端上に微小き裂がある場合の解析を行い, き裂先端の応力拡大係数は特異 応力場の影響を受けて非常に大きくなるが，き裂が長くなるに伴いその影響は無くなることを示した. Sukumar ら(Sukumar, et al., 2004)は二次元接合体の界面き裂に対寸る複素応力拡大係数をエンリッチ有限要素を用いて求 める方法を提案した. Johnson と Qu (2007)は, 有限要素法を用いてき裂先端領域の経路独立積分を評価し, 温度 分布のある二相体界面き裂の応力拡大係数を求める方法を提案した. Tvergaard と Hutchinson (2008)は, 二相体の 界面を進展に対するき裂先端のモード I, II と III の影響を調べた．Chiu と Lin(2009)は，電子パッケージの三次元 界面き裂，特にき裂前縁が湾曲している場合のき裂先端に沿って応力拡大係数，エネルギ開放率および位相角の 破壞力学パラメータの分布を仮想き裂進展法により求めた。 また, Nagai ら (Nagai, et al., 2007)は二相異方性体の 三次元界面き裂の応力拡大係数を $\mathrm{M}$ 積分で求めた. 最近, Badrinath ら(Badrinath and Henrik, 2013)は, 商用有限要 素解析ソフトを用いて，薄膜界面き裂の解析を行い，成長する界面き裂の形状の決定法を報告している.

特異応力場などの応力勾配がある場における界面き裂に関する研究の多くは二次元き裂(Yuuki and Cho, 1989, Akisanya and Fleck, 1997, Ioka, et al., 2002)であり, 三次元き裂(Nakamura and Parks, 1988, Nakamura, 1991, Ghahremani and Shih, 1992)の解析は少ない. ところで, 著者らはこれまで三次元異材接合体の界面端角部近傍の特異応力場の 特性を調べ, 特に界面上の応力分布について, 側面と界面の交線である応力特異線との関係を明らかにしてきた (古口他, 2012). 本研究では界面端角部にき裂が無い状態からき裂が生じた場合を考え, き裂発生前に存在して いる特異応力場がき裂発生により変化する様子を明らかにし, き裂先端の応力拡大係数のき裂縁上における分布 およびき裂面形状とエネルギ開放量の関係を明らかにして, 初期界面き裂形状について考察する。本論文では, 緒言に続いて第 2 章で解析方法を説明し, 第 3 章で解析モデルおよび解析条件, 第 4 章で解析結果を示し, 第 5 章で微小界面き裂の解析結果を示寸と共に考察を行い, 第 6 章で得られた結果をまとめる.

\section{2. 解 析 方 法}

本研究では, 三次元異材接合体内における任意の点の変位を, 次の境界積分方程式で求める.

$$
u_{i}(q)=\int_{\Omega}\left[U_{i j}(q, Q) t_{j}(Q)-T_{i j}(q, Q) u_{j}(Q)\right] d s(Q)
$$

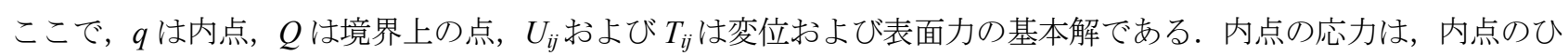
ずみを次式で求め, フックの法則に代入して求める.

$$
u_{i, j}(q, Q)=\int_{\Omega}\left[U_{i k, j}(q, Q) t_{k}(Q)-T_{i k, j}(q, Q) u_{k}(Q)\right] d s(Q)
$$

ここで, $U_{i j, k}$ と $T_{i j, k}$ は内点 $q$ における変位と表面力の基本解の微分である. 本研究では, 基本解に Rongved $の 二$ 相接合体の解を使用している，そのため界面上の要素分割をする必要が無くなり，これにより界面上の応力分布 を高精度に求めることができる.

つぎに，三次元接合体の接合界面端および界面と側面およびき裂面との交線である応力特異線上の点における 特異性のオーダを求める方法の概略を説明する.特異性のオーダを求めたい点に原点を有する球座標系を考える. その後, 特異点を中心とする球面を考え, 球内部が特異応力場の特性を有する領域であるとする. 球を四角錐の 要素に分割し, 球内部の特異応力場に対して変位場を考え, これを仮想仕事の原理に基づく有限要素法に適用寸 る. 式を整理すると, 次式の $p$ に関する固有方程式が得られる. 特異応力場の特異性のオーダ入は式(3)の固有方 程式を解くことにより求められる. ここで固有值 $p$ は特異性のオーダ $\lambda と \lambda=1-p$ の関係がある. 


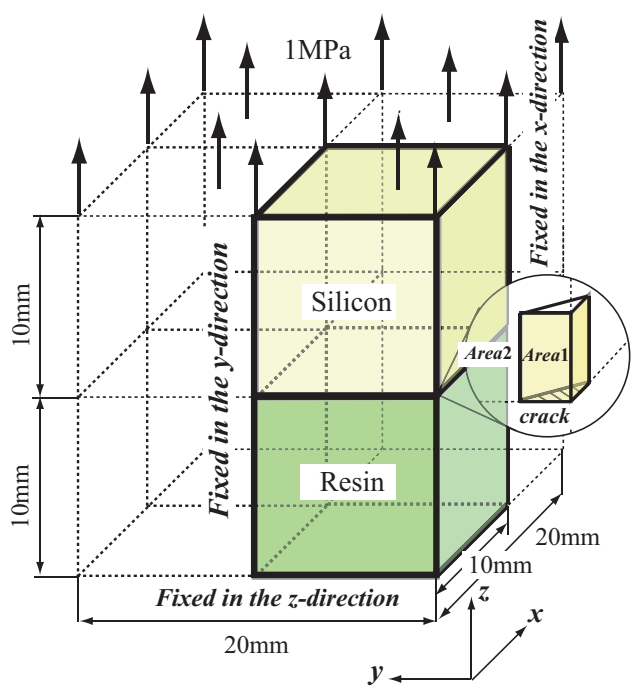

Fig.2 Three-dimensional bonded structures with a small crack at vertex

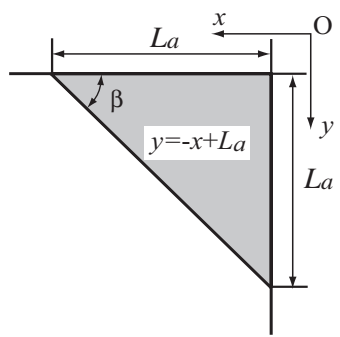

Type A

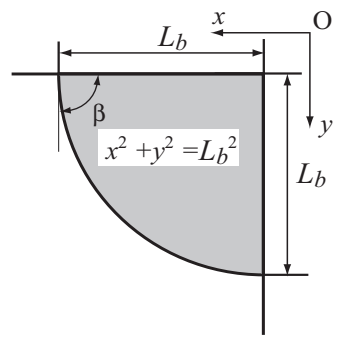

Type B

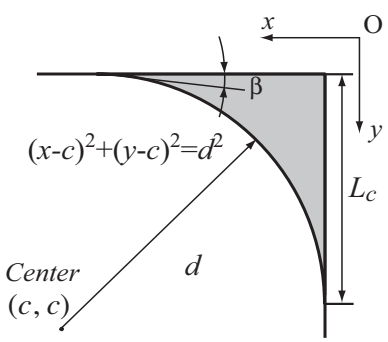

Type C

Fig.3 Shape of interface crack at the vertex

Table 1 Material properties

\begin{tabular}{|c|c|c|}
\hline & Silicon & Resin \\
\hline Young's modulus, GPa & 166.01 & 2.74 \\
\hline Poisson's ratio & 0.26 & 0.38 \\
\hline
\end{tabular}

$$
\left(p^{2}[\mathbf{A}]+p[\mathbf{B}]+[\mathbf{C}]\right)\{\mathbf{u}\}=\mathbf{0}
$$

ここで, $[\mathbf{A}],[\mathbf{B}],[\mathbf{C}]$ は接合体の材料特性および接合体形状により決まる有限要素法の剛性マトリックスである. また，\{u\} は有限要素法で球面を分割した要素の節点変位のベクトルである.

\section{3. 解析モデルおよび解析条件}

図 2 は界面角部に微小な界面き裂がある二相接合体の解析モデルである.上の材料は Silicon, 下の材料は Resin である，界面角部に微小なき裂を設けるために，図 2 に示すようにき裂面上部に細長い微小領域を設け，領域解 法を用いて応力解析を行なっている. 界面き裂の形状を図 3 に示すが，領域解法の微小領域のサイズは， $z$ 軸方 向長さを $0.05 \mathrm{~mm}$ とし， $x$ - $y$ 面内の長さおよび形状は図 3 と同様である. 図に示すように三角形形状をしたものを Type A, 円弧が角部から見て凸になっているものを Type B, 円弧が角部から見て凹になっているものを Type C と呼ぶことにする。き裂面のサイズは面積が同じになるように決めた．それぞれ， $L_{a}=2.69 \times 10^{-4} \mathrm{~mm}, L_{b}=2.15 \times$ $10^{-4} \mathrm{~mm}, L_{c}=3.05 \times 10^{-4} \mathrm{~mm}, d=6.82472 \times 10^{-4} \mathrm{~mm}$ および $c=6.10352 \times 10^{-4} \mathrm{~mm}$ である. Resin 底面の $z$ 方向変位を固定 し, Silicon 上面に外力として $\sigma_{0}=1 \mathrm{MPa}$ の引張応力を与えた. モデルサイズは Silicon, Resin 共に高さ $10 \mathrm{~mm}$, 幅 


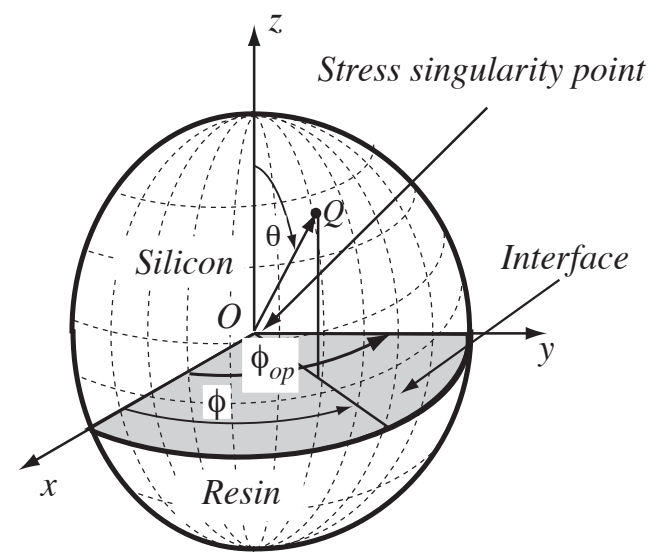

(a) Mesh on a unit sphere with an origin at a vertex

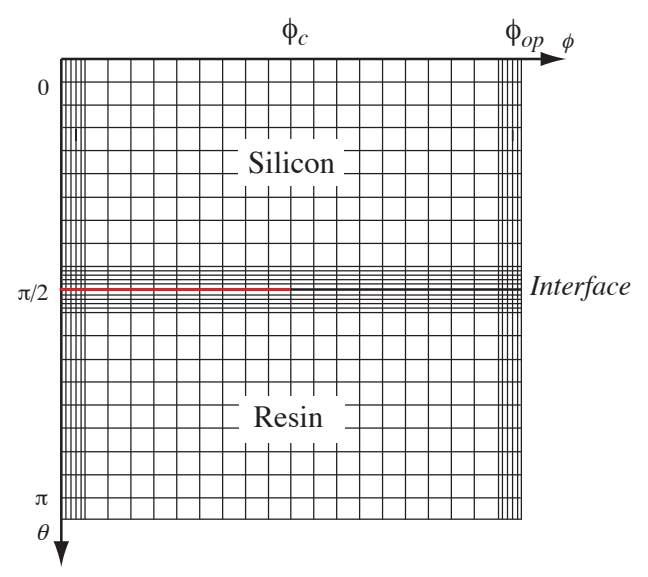

(b) Mesh on the developed $\theta \times \phi$ plane

Fig.4 Finite element model for eigen analysis

$20 \mathrm{~mm}$ となっている．解析時間の短縮のため対称性を考慮した $1 / 4$ モデルで解析を行った．解析に用いた各材料 の物性值を表 1 に示す.

\section{4. 解析結果}

\section{$4 \cdot 1$ 固有值解析の結果}

はじめに，き裂が無い場合の応力特異性のオーダを求める. 固有值解析に用いた有限要素モデルの要素分割図 を図 4(a), (b)に示寸. 図4(a)は特異点を原点とする単位球表面を角度 $\phi$ と $\theta$ 方向に分割したもので, 図 4(b)は図 4(a) を $\theta$ - $\phi$ 平面に展開したものである. 接合界面角部の応力特異性および応力特異線上の応力特異性を詳細に調べるた めに，界面および側面に近いところでは要素サイズを小さくした．図4(a),4(b)のように角部の側面間の開き角を $\phi_{o p}$ とすると, $\phi_{o p}=90^{\circ}$ (角部), $\phi_{o p}=180^{\circ}$ (特異応力線上) の場合の固有值解析を行い, 特異性のオーダ $\lambda$ を求めた. 表 2 にその固有值解析の結果を示寸．表には特異性を有する固有值のみを載せてある.

界面にき裂がある場合の固有值解析のためのモデルは, 図 4(b)に示寸界面 $\theta=\pi / 2$ 上の赤い線で示した線上にあ る材料 1,2 の節点を各々別の節点に設定することで作成できる. なお，き裂面は $\theta=\pi / 2, \phi_{o p}=2 \pi, 0 \leq \phi \leq \phi_{\mathrm{c}}(=\pi)$ の領域で表される. 解析に用いた要素サイズは $\theta \times \phi=9^{\circ} \times 9^{\circ}$ である. 界面上および特異応力線近傍では, 要素をさら に 5 分割し刻み幅を 1.8 とした. 表 3 に固有值解析により得られたき裂モデルの特異性のオーダ入を示寸. 表 3 に 示すように特異性のオーダが 0.5 のものが 3 つある.このうちの 2 つは共役複素数であり, 界面き裂の場合に特 異応力場の振動特性を表すものである.

Table 2 Eigenvalues for Silicon-Resin interface

\begin{tabular}{|c|c|c|c|}
\hline \multicolumn{2}{|c|}{ Stress singularity point, $\phi_{\text {op }}=90^{\circ}$} & \multicolumn{2}{c|}{ Stress singularity line, $\phi_{\text {op }}=180^{\circ}$} \\
\hline $\operatorname{Re}\left(\lambda_{\text {vertex }}\right)$ & $\operatorname{Im}\left(\lambda_{\text {vertex }}\right)$ & $\operatorname{Re}\left(\lambda_{\text {line }}\right)$ & $\operatorname{Im}\left(\lambda_{\text {line }}\right)$ \\
\hline 0.395 & 0.000 & 0.318 & 0.000 \\
\hline
\end{tabular}

Table 3 Eigenvalues at a point on crack front line

\begin{tabular}{|c|c|c|c|c|c|}
\hline $\operatorname{Re}\left(\lambda_{1}\right)$ & $\operatorname{Im}\left(\lambda_{1}\right)$ & $\operatorname{Re}\left(\lambda_{2}\right)$ & $\operatorname{Im}\left(\lambda_{2}\right)$ & $\operatorname{Re}\left(\lambda_{3}\right)$ & $\operatorname{Im}\left(\lambda_{3}\right)$ \\
\hline 0.50 & 0.000 & 0.50 & 0.0592 & 0.50 & -0.0592 \\
\hline
\end{tabular}

Table 4 Eigenvalues at a crosspoint of side surface and crack front line

\begin{tabular}{|c|c|c|c|c|c|}
\hline \multicolumn{2}{|c|}{ Type $\mathrm{A}\left(\beta=45^{\circ}\right)$} & \multicolumn{2}{c|}{ Type $\mathrm{B}\left(\beta=90^{\circ}\right)$} & \multicolumn{2}{c|}{ Type $\mathrm{C}\left(\beta=27.5^{\circ}\right)$} \\
\hline$\lambda_{1}$ & $\lambda_{2}$ & $\lambda_{1}$ & $\lambda_{2}$ & $\lambda_{1}$ & $\lambda_{2}$ \\
\hline 0.457 & 0.316 & 0.664 & 0.500 & 0.371 & 0.139 \\
\hline
\end{tabular}




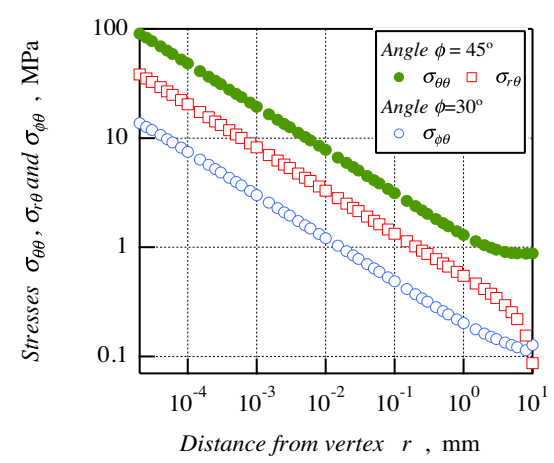

(a) Distribution of $\sigma_{i j}^{\text {vertex }}$ against distance from the vertex

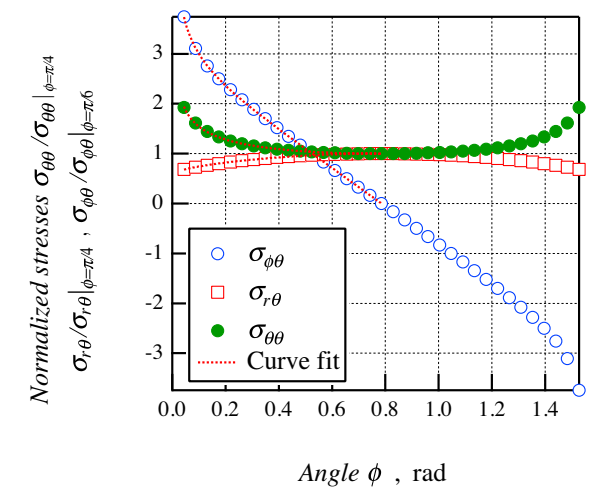

(b) Distribution of $\sigma_{i j}^{\text {vertex }} /\left.\sigma_{i j}^{\text {vertex }}\right|_{\phi=45^{\circ}, 30^{\circ}}$ against angle $\phi$

Fig. 5 Distributions of stress $\sigma_{i j}$ in two-phase models against the distance $r$ and the angle $\phi$

表 4 には, 界面き裂先端と側面との交点における特異性のオーダをそれぞれのき裂タイプ毎に示す. Type A, Type B, Type C ともに, 特異性を示寸特異性のオーダが 2 つあり, Type B の方が特異性のオーダの值は大きい. 3 種類の微小き裂を比較すると Type C のモデル形状が最も特異性のオーダの值が小さい.

\section{$4 \cdot 2$ 境界要素法の解析結果}

\section{$4 \cdot 2 \cdot 1$ 応力分布（微小き裂の無い場合）}

はじめに, 図 2 に示した微小き裂の無いモデルに対する界面端角部近傍の特異応力場の応力分布を調べる. そ こで, 境界要素法で得られた直交座標系の応力成分を接合界面端角部の応力特異点を原点とする球座標系（図 1 を参照）の応力成分に変換する. 変換して得られた応力分布を図 5(a), (b)に示す. 特に, 界面き裂に関係する応 力成分 $\sigma_{\theta \theta}{ }^{\text {vertex }}, \sigma_{r \theta}^{\text {vertex }}, \sigma_{\phi \theta}^{\text {vertex }}$ を特異点からの距離 $r$ および側面からの角度 $\phi に$ 対して示してある. き裂の無いモデ ルにおける角部近傍の応力を示寸意味で添字にvertex を付けてある. 図5(a)が角部からの距離 $r$ に対する応力分 布, 図 5(b)が特異応力線からの角度 $\phi に$ 対するものである. なお, 図 5(b)では $\sigma_{\theta \theta}{ }^{\text {vertex }}, \sigma_{r \theta}{ }^{\text {vertex }}$ は $\phi=45^{\circ}$ の応力で正規 化し， $\sigma_{\phi \theta}^{\text {vertex }}$ は $\phi=30^{\circ}$ の応力で正規化してある. 図 5(a)の分布から各応力成分は角部からの距離 $r$ に対してお互い に平行であることがわかる. また, この直線の傾きは 0.395 で, 表 2 の界面端角部における特異応力場の特異性 のオーダと同じであった．これまでの研究で, 三次元接合体界面端角部の特異応力場は, 対数特異性を無視する と球座標系で次式のように表すことができる(Koguchi and da Costa, 2010).

$$
\sigma_{i j}(r, \theta, \phi)=K_{1 i j} f_{1 i j}(\theta, \phi) r^{-\lambda_{\text {verex }}}+K_{2 i j} f_{2 i j}(\theta, \phi)
$$

ここで, $K_{1 i j}$ は応力 $\sigma_{i j}$ の特異応力場の強さ, $f_{1 j}(\theta, \phi)$ は角度関数である.

つぎに界面上 $(\theta=\pi / 2)$ の忘力について詳しく調べる. 界面上の応力 $\sigma_{i j}^{\text {vertex }}$ については, 式(4)を式(5)のように書く ことにする．その時，角度関数は式(6)〜(8)のように表すことができる.

$$
\begin{aligned}
& \sigma_{i j}^{\text {vertex }}(r, \pi / 2, \phi)=K_{1 i j} f_{1 i j}^{\phi}(\phi) r^{-\lambda_{\text {verex }}}+K_{2 i j} f_{2 i j}^{\phi}(\phi) \\
& f_{1 \theta \theta}^{\phi}(\phi)=L_{1 \theta \theta}\left\{(\sin \phi)^{-\lambda_{\text {line }}}+(\cos \phi)^{-\lambda_{\text {line }}}\right\}+L_{2 \theta \theta} \\
& f_{1 r \theta}^{\phi}(\phi)=L_{1 r \theta}\left\{(\sin \phi)^{-\lambda_{\text {line }}} \cos \phi+(\cos \phi)^{-\lambda_{\text {line }}} \sin \phi\right\}+L_{2 r \theta}\left\{(\sin \phi)^{1-\lambda_{\text {line }}}+(\cos \phi)^{1-\lambda_{\text {line }}}\right\}+L_{3 r \theta}(\sin \phi+\cos \phi) \\
& f_{1 \phi \theta}^{\phi}(\phi)=L_{1 \phi \theta}\left\{(\sin \phi)^{-\lambda_{\text {line }}} \cos \phi-(\cos \phi)^{-\lambda_{\text {ine }}} \sin \phi\right\}+L_{2 \phi \theta}\left\{(\sin \phi)^{1-\lambda_{\text {line }}}-(\cos \phi)^{1-\lambda_{\text {line }}}\right\}+L_{3 \phi \theta}(\sin \phi-\cos \phi)
\end{aligned}
$$




$$
+L_{4 \phi \theta}(\cos \phi-\sin \phi)
$$

応力特異点からの距離 $r$ に対する応力分布に関して, 応力 $\sigma_{\theta \theta}$ については式(5)の $f_{1 \theta \theta}^{\phi}(\phi)=f_{2 \theta \theta}^{\phi}(\phi)=1$ とした式を 用いて図 5(a)の応力分布を近似し, 特異応力場の強さを $K_{1 \theta \theta}$ を求める. 図 $5(\mathrm{a})$ の $\sigma_{\theta \theta}$ の分布は $\phi=45^{\circ}$ におけるもので あることを考慮して，図 5(b)の $\sigma_{\theta \theta}$ の分布を式(6)で近似する。他の応力成分についても同様な近似を行い，各式の 係数を求めた. 得られた各係数の值を表 5 に示す.

Table 5 Values of coefficients in the expressions of stress

\begin{tabular}{|c|c|c|c|c|c|c|}
\hline \multirow{2}{*}{$\sigma_{\theta \theta}^{\text {vertex }}$} & $K_{1 \theta \theta}, \mathrm{MPa} \cdot \mathrm{mm}^{\lambda \text { vertex }}$ & $K_{2 \theta \theta}, \mathrm{MPa} \cdot \mathrm{mm}$ & $L_{1 \theta \theta}$ & $L_{2 \theta \theta}$ & - & - \\
\hline & 1.26 & 0.0594 & 0.64 & -0.43 & - & - \\
\hline \multirow{2}{*}{$\sigma_{r \theta}^{\text {vertex }}$} & $K_{1 r \theta}, \mathrm{MPa} \cdot \mathrm{mm}^{\lambda \text { vertex }}$ & $K_{2 r \theta}, \quad \mathrm{MPa} \cdot \mathrm{mm}$ & $L_{1 r \theta}$ & $L_{2 r \theta}$ & $L_{3 r \theta}$ & \\
\hline & 0.535 & -0.00154 & -0.0298 & 0.254 & 0.458 & \\
\hline \multirow{2}{*}{$\sigma_{\phi \theta}^{\text {vertex }}$} & $K_{1 \phi \theta}, \mathrm{MPa} \cdot \mathrm{mm}^{\text {גvertex }}$ & $K_{2 \phi \theta}, \quad \mathrm{MPa} \cdot \mathrm{mm}$ & $L_{1 \phi \theta}$ & $L_{2 \phi \theta}$ & $L_{3 \phi \theta}$ & $L_{4 \phi \theta}$ \\
\hline & 0.194 & 0.0263 & 1.012 & 0.826 & 0.0672 & 1.919 \\
\hline
\end{tabular}

\section{$4 \cdot 2 \cdot 2$ 応力分布（微小き裂のある場合）}

つぎに，き裂面形状が Type A の場合の解析結果について説明する. 図 6 は前述したのと同様に界面端角部か らの距離 $r$ に対する $\sigma_{\theta \theta}$ の界面上の分布の両対数プロットであるが，様々な角度饾対して示してある. ここで， 接合界面上のき裂面の先端をき裂面前縁と呼ぶことにする. 図 6 から，応力分布のプロットは $r$ が $10^{-3} \sim 1 \mathrm{~mm}$ の 範囲である一定の傾きを持った直線となっており, き裂面前縁に近づくにともない応力が大きくなっていること がわかる．また，側面からの角度 $\phi に$ 対しては $\phi=45^{\circ}$ に関し対称になっている．微小き裂を角部に設けたことで， き裂発生前の応力場にき裂の応力場が重畳され，応力場がより複雑になったと考えられる. そこで，図 6 に示し た応力分布の $r$ が $10^{-3} \sim 1 \mathrm{~mm}$ の範囲を前述した式(4)を用いて最小二乗法で近似した. なお, 式(4)中の特異性才一 ダ $\lambda_{\text {vertex }}$ には表 2 に示した值 0.395 を用いた. 図 7 は図 6 のき裂面前縁近傍の応力分布の拡大図である. 図中の実 線は前述の式で近似して得られた直線である. 図中の $p_{1} \sim p_{5}$ は角度 $\phi$ を $45^{\circ}, 35^{\circ}, 25^{\circ}, 15^{\circ}, 5^{\circ}$ とて界面角部 から引いた直線とき裂面前縁との交点の位置, 寸なわち, それぞれの角度に対するき裂先端の位置を表している. ちなみに，界面角部からき裂前縁までの距離は， $p_{1}$ から順に $p_{5}$ まで 0.190788, 0.193731, 0.203032, 0.220303， $0.249056 \mu \mathrm{m}$ である. この図 7 のように角部を原点とする球座標系に対してプロットすると, $\phi$ を変えると角部か らき裂面前縁までの距離が変わるため, 応力の最大值の場所が異なる. 図 7 には $\phi$ 方向の対称性を考慮して $\phi=0^{\circ}$ 〜 45の結果のみを示している. これを見ると, き裂の影響範囲を超えた領域の応力は $\lambda=0.395$ の特異応力場に支

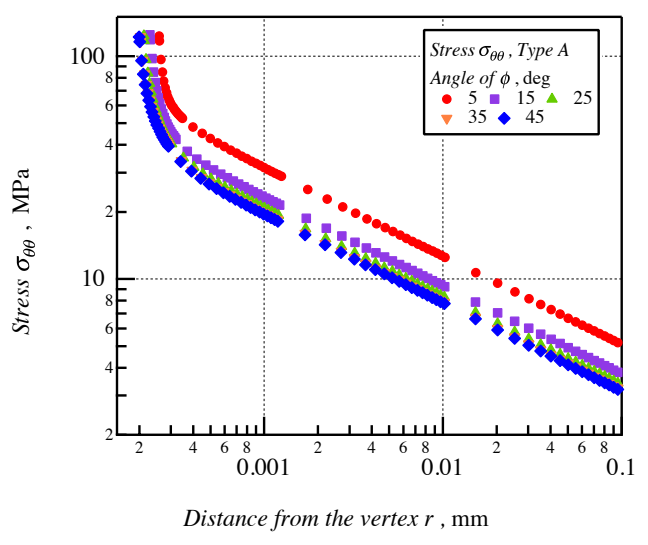

Fig.6 Distributions of $\sigma_{\theta \theta}$ against distance from the vertex (Type A)

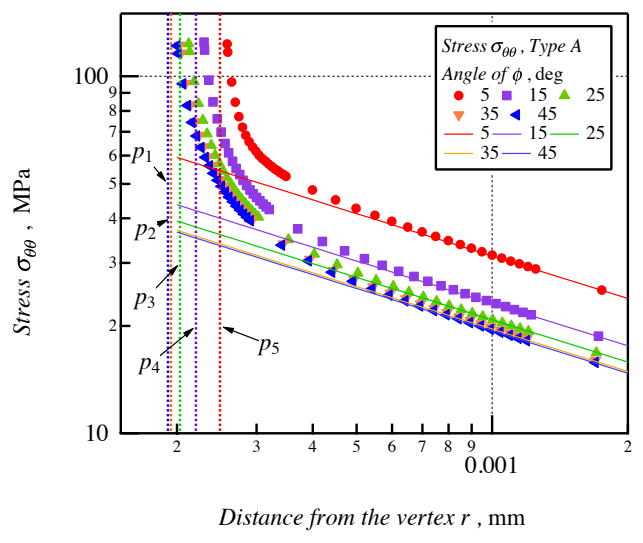

Fig.7 Distribution of $\sigma_{\theta \theta}$ near the crack (Enlargement) 
配されていることがわかる，き裂面前縁近傍の応力はこの傾きとは別の傾きを持っている．ちなみに， $p_{5}$ の位置 にき裂先端があるとして, 図 7 の応力が直線で表される角部からの距離はおよそ $0.0006 \mathrm{~mm}$ であるから, き裂の 影響範囲はき裂長さの 2.5 倍程度であることがわかる. き裂面前縁近傍の応力はき裂の影響を受けて大きくな っているが，界面端近傍全体で見ると異材接合体の角部の特異性に支配されている.

つぎに，き裂面前縁の応力場を明らかにするためにき裂面前縁に沿う円柱座標系を導入する．図 8 に示すよう に座標系のパラメータをとる.この図で $O_{i}(i=1,2, \cdots \cdots, n)$ が円柱座標系の原点, $\Theta$ 界面からの角度, $r_{i}$ はき 裂面前縁に対寸る法線を含む面における原点 $O_{i}$ からの距離である。この円柱座標系の取り方についてそれぞれ Type A，Type B, Type C 毎に図 9(a)，(b)，(c)に示寸．原点 $O_{i}$ は，き裂発生前の界面端角部(図 8 の $O$ )の球座標系

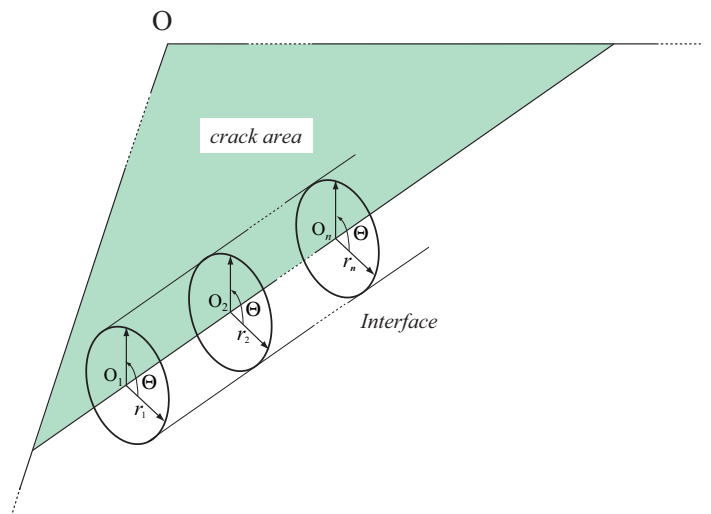

Fig.8 Cylindrical coordinate systems located at a point on the front line of crack tip

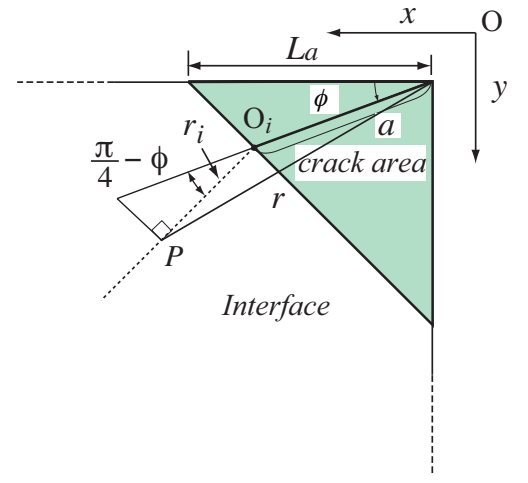

(a) Type A

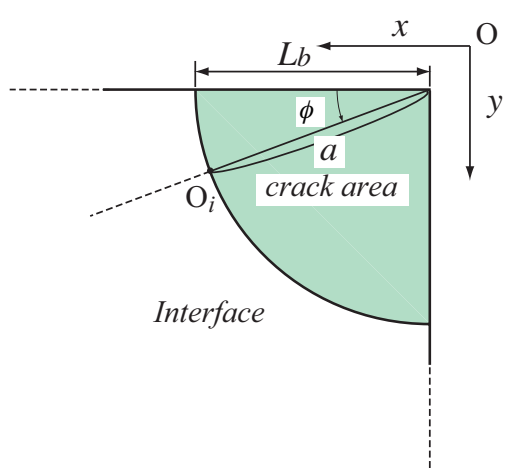

(b) Type B

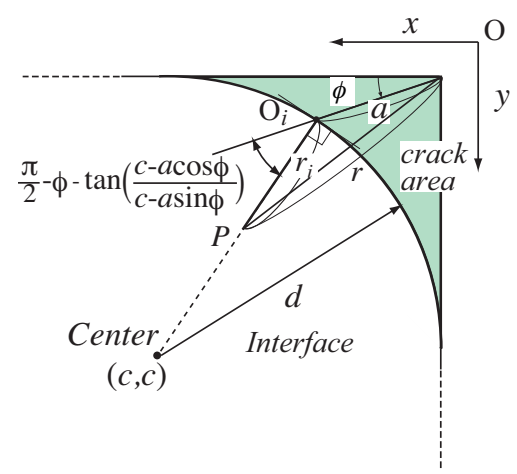

(c) Type C

Fig.9 Cylindrical coordinate systems on front line of crack tip for each type of crack

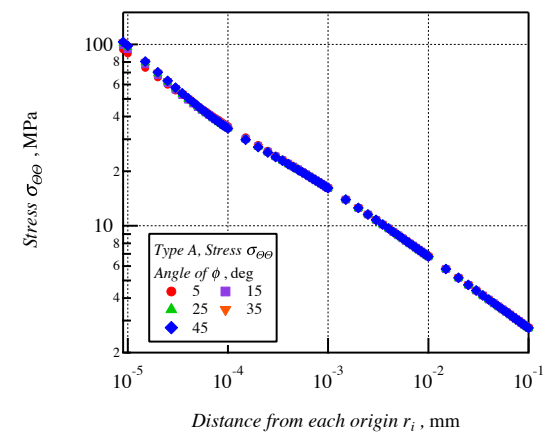

(a) Type A

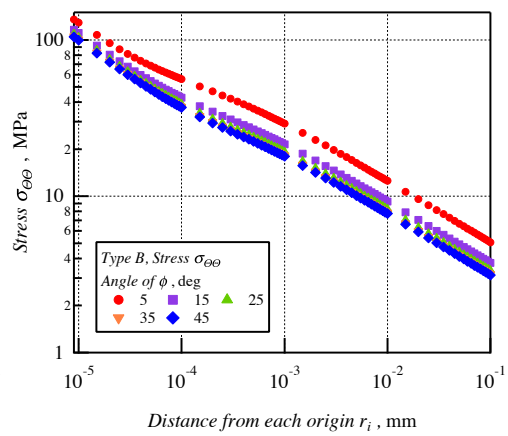

(b) Type B

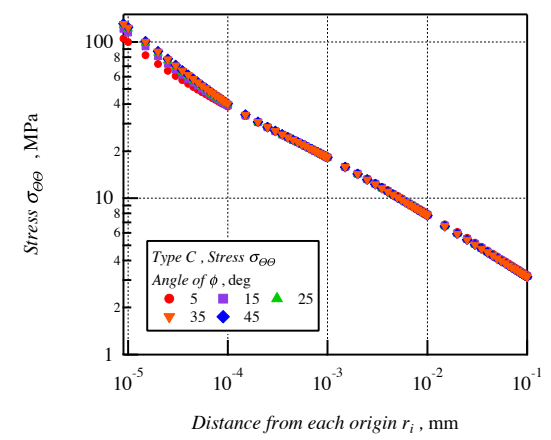

(c) Type C

Fig.10 Distributions of stress $\sigma_{\Theta \Theta}$ against the distance $r_{i}$ for three types of crack 
で側面からの角度を $\phi$ として, 界面上で角部特異点から動径方向に描いた直線とき裂面前縁との交点にとった.

\section{$4 \cdot 2 \cdot 3$ 微小き裂前縁における $\sigma_{\Theta \Theta}$ の分布（円柱座標系）}

微小き裂形状が Type $\mathrm{A}$, Type $\mathrm{B}$, Type $\mathrm{C}$ のものについて, 応力を前述の円柱座標系に変換して得られた分布を それぞれ図 10(a)，(b)，(c)に示寸．このグラフは全て両対数であり，横軸にき裂面前縁からの距離 $r_{i}$ をってい る. 図 10(a), (b), (c)に共通して言えることは, 角部を原点とした球座標系を用いてプロットした図 6 と同様に, き裂面前縁近傍で応力が大きくなっていることである. また, Type A と Type C の場合はき裂面前縁から離れた ところで，異なる角度 $\phi に$ 対する応力がほぼ同じになっている. Type B の場合， $\phi=45^{\circ} に$ 近づくに伴い全体的に小 さい応力になっており，側面に近い角度

つぎに, 図 10 の応力分布にき裂が無い二相接合体モデルの応力分布を重㸚て両者を比較する. 図 5 の応力分布 に対する近似式を用いると界面端角部近傍の界面上の任意の点の応力を求めることができる. そこで, 図 10 の応 力分布と同一座標の二相接合体における応力を求める. その際, 用いる式(5)の中の $r$ を次式のように変えること により，き裂先端の座標原点 $O_{i}$ からの距離 $r_{i}$ に対寸る応力を求めることができる.

$$
r=\left\{\begin{array}{cc}
\sqrt{r_{i}^{2}+a(\phi)^{2}-2 r_{i} a(\phi) \cos \left(\frac{3 \pi}{4}+\phi\right)} & \text { (Type A) } \\
a+r_{i} & \text { (Type B) } \\
\sqrt{r_{i}^{2}+a(\phi)^{2}+2 r_{i} a(\phi) \cos (\phi+\alpha)} & \text { (Type C) } \\
\text { where } \alpha=\tan ^{-1}\left(\frac{c-a(\phi) \cos \phi}{c-a(\phi) \sin \phi}\right) &
\end{array}\right.
$$

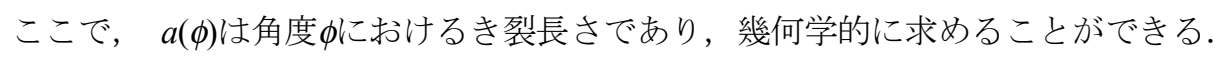

き裂の無いモデルの応力を微小き裂モデルに対する結果に重祆て図 11 に示寸.き裂前縁近傍では二相接合体の 応力はき裂を有するモデルの応力分布よりも小さく, 傾きもき裂を有するモデルのものより緩やかになっている. また，二相体の応力に大小関係の違いはあるが，傾きに大きな違いは無いことがわかる. Type A と Type B の場 合， $r_{i}>5 \times 10^{-4} \mathrm{~mm}$ の範囲でき裂を有するモデルの応力とき裂の無いモデルの応力はほぼ同じになっている.

つぎにき裂を有するモデルの応力をき裂の無いモデルの応力で割った結果を図 12 に示寸.これらの図はき裂前 縁近傍を拡大したものであり，き裂から離れたところで応力分布が一定になっていること，さらにき裂先端から $10^{-5} \mathrm{~mm}$ 離れた位置でみると応力が角部の特異応力場の3〜4 倍大きくなっていることがわかる. ちなみに, Type A, Type B，Type C の側面上のき裂長さは，それぞれ $2.69 \times 10^{-4} \mathrm{~mm}, 2.15 \times 10^{-4} \mathrm{~mm}, 3.05 \times 10^{-4} \mathrm{~mm}$ である. 図 12 か ら無次元化された応力の分布は, き裂の長さと同程度, き裂先端から離れると側面からの角度 $\phi に$ 依らず一致す ることがわかる．このことから特異応力場で応力を無次元化することにより，特異場内のき裂を一様応力場中の き裂のように扱うことができると言える.

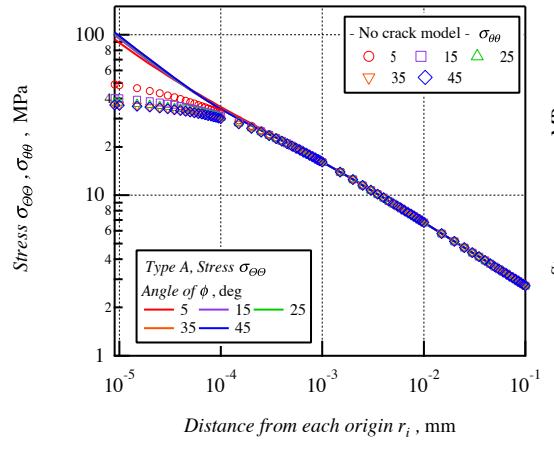

(a) Type A

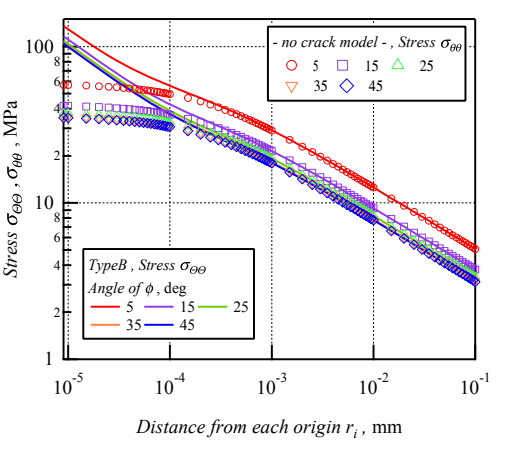

(b) Type B

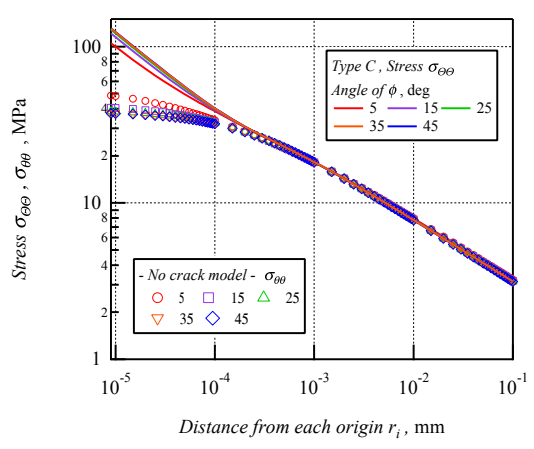

(c) Type $\mathrm{C}$

Fig.11 Comparison of distributions of stress $\sigma_{\Theta \Theta}$ near the crack front line 


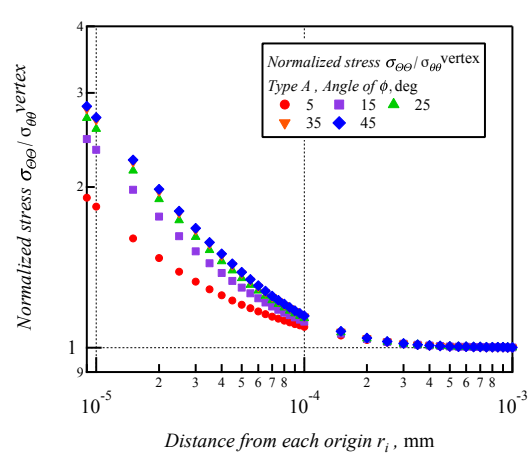

(a) Type A

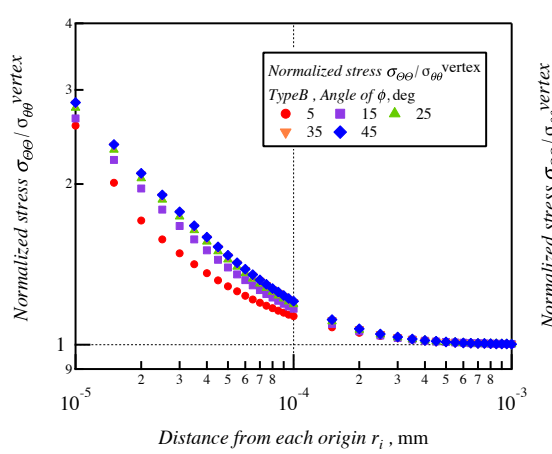

(b) Type B

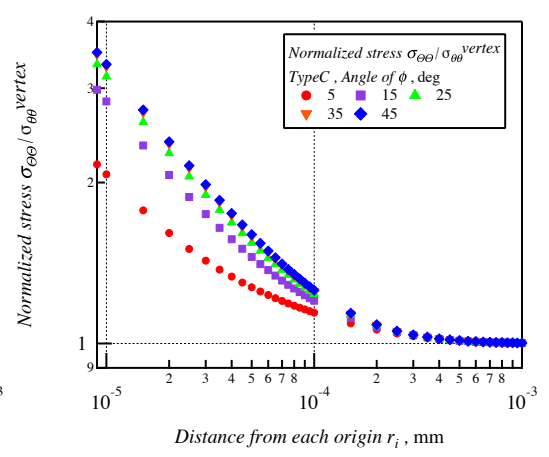

(c) Type C

Fig.12 Normalized stress $\sigma_{\Theta \Theta} / \sigma_{\Theta \Theta}^{\text {vertex }}$ for different types of crack

\section{5. 微小界面き裂の解析}

\section{$5 \cdot 1$ 応力拡大係数}

前述したように前章で求めた無次元化応力の分布は, 一様応力場中の界面き裂に対する分布と見なすことがで

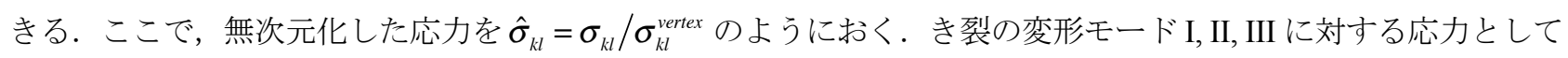
$\hat{\sigma}_{\Theta \Theta}, \hat{\sigma}_{R \Theta}, \hat{\sigma}_{t \Theta}$ を考えることができるが，本章では最もき裂発生に影響の大きい $\hat{\sigma}_{\Theta \Theta}$ について調べる. また，図 12 の横軸を任意の長さ $\ell て ゙$ 除し, 無次元化する. 角部微小き裂近傍の無次元応力場は次式のように表すことができる.

$$
\hat{\sigma}_{\Theta \Theta}(\hat{R}, \Theta)=\left(K_{1 \Theta \Theta}(\Theta) \hat{R}^{i \varepsilon}+\bar{K}_{1 \Theta \Theta}(\Theta) \hat{R}^{-i \varepsilon}\right) \hat{R}^{-0.5}+K_{2 \Theta \Theta}(\Theta)
$$

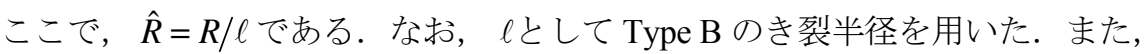

$$
K_{1 \ominus \Theta}=K_{1 \ominus \Theta}^{\mathrm{Re}}+i K_{1 \ominus \Theta}^{\mathrm{Im}}=K_{\mathrm{I}}^{*}\left(f_{1 \Theta \Theta}^{\mathrm{Re}}+i f_{1 \Theta \Theta}^{\mathrm{Im}}\right), \quad \bar{K}_{1 \ominus \Theta}=K_{1 \Theta \Theta}^{\mathrm{Re}}-i K_{1 \Theta \Theta}^{\mathrm{Im}}=K_{\mathrm{I}}^{*}\left(f_{1 \ominus \Theta}^{\mathrm{Re}}-i f_{1 \ominus \Theta}^{\mathrm{Im}}\right)
$$

KI はモード I の応力拡大係数である.この式を式(10)に代入して整理すると

$$
\hat{\sigma}_{\Theta \Theta}(\hat{R}, \Theta)=2 K_{\mathrm{I}}^{*}\left\{f_{1 \Theta \Theta}^{\mathrm{Re}} \cos (\varepsilon \ln \hat{R})-f_{1 \Theta \Theta}^{\mathrm{Im}} \sin (\varepsilon \ln \hat{R})\right\} \hat{R}^{-0.5}+K_{2 \Theta \Theta}^{*}(\Theta)
$$

が得られる. 式(12)を図 12 に適用し, 応力拡大係数 $K_{\mathrm{I}}^{*}$ を決定する. その前に, 複素角度関数を求めておく必要 がある. 角度関数は式(3)の固有方程式から得られる固有值に対する固有ベクトルから得ることができる．その結 果, $\Theta=62^{\circ}$ で $\left|f_{1 \Theta \Theta}^{\mathrm{Re}}+i f_{1 \Theta \Theta}^{\mathrm{Im}}\right|$ は最大となり, その最大值で複素角度関数を正規化する. その結果から $\Theta=0^{\circ}$ におけ

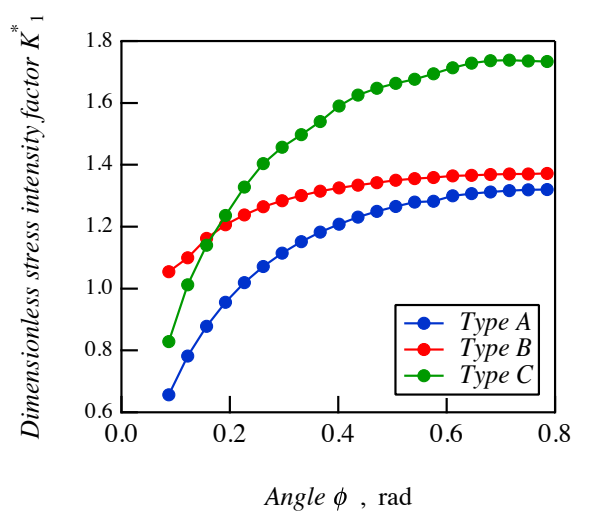

(a) Dimensionless $K_{\mathrm{I}}^{*}$

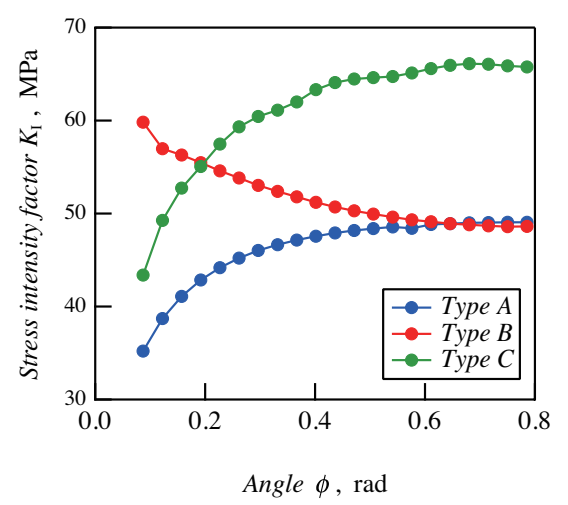

(b) $K_{\mathrm{I}}$

Fig.13 Distribution of stress intensity factor against the angle $\phi$ 
る $f_{1 \Theta \Theta}^{\mathrm{Re}}$ と $f_{1 \Theta \Theta}^{\mathrm{Im}}$ を求めると, それぞれ 0.106502 と 0.35272 が得られた. 図 13 は求められた $K_{\mathrm{I}}$ の側面からの角度 $\phi に$ 対寸る分布である. 図 13(a)は無次元応力から求められた無次元応力拡大係数 $K_{\mathrm{I}}^{*}$ である. 側面に近くなるに伴い 小さくなっている. また, 式(5), (6)から得られる応力を無次元応力拡大係数に掛けることにより応力拡大係数 $K_{\mathrm{I}}$ を求めた，その結果を図 13(b)に示す。この図から, Type B の応力拡大係数は, 側面に近づくに伴い大きくなる のに対して, Type A と Type C のそれは小さくなる. 表 4 にき裂前縁が側面と交わる点における応力特異点の特 異性のオーダを示してある. 特異性のオーダの值は, Type B の場合 0.664 でき裂の 0.5 より大きいため, 側面に 近づくに伴い大きくなる. Type A, Type C の場合ともに 0.5 より小さい. 0.5 との差は Type A の場合 0.043 , Type C の場合 0.129 で, 図 13(b)を見ると, 差の大きい Type C の方が応力拡大係数の減少が大きい. このようにき裂 前縁の応力拡大係数の分布は, 側面とき裂前縁の交点における特異応力場の影響を受けていることがわかる.

\section{$5 \cdot 2$ エネルギ解放量}

前章まで三次元特異応力場に微小き裂が発生したときの応力場の変化について調べてきた．本章では，き裂が 発生する際に解放されるエネルギを求める. 特異応力場から微小き裂が発生する際, き裂面に分布していた応力

$\left(\sigma_{r \theta}, \sigma_{\theta \theta}, \sigma_{\phi \theta}\right)$ がき裂面に対してな寸仕事は, 応力と微小面積の積とき裂面の相対変位 $\left(\Delta u_{r}, \Delta u_{\theta}, \Delta u_{\phi}\right)$ と掛けてき裂 面について積分することにより求めることができる. すなわち,

$$
\Delta G=\int_{0}^{\frac{\pi}{2}} \int_{0}^{a(\phi)}\left\{\sigma_{r \theta}^{\text {vertex }}(r, \phi) \Delta u_{r}(r, \phi)+\sigma_{\theta \theta}^{\text {vertex }}(r, \phi) \Delta u_{\theta}(r, \phi)+\sigma_{\phi \theta}^{\text {vertex }}(r, \phi) \Delta u_{\phi}(r, \phi)\right\} r d r d \phi
$$

ここで, 応力は式(5)〜(8)を用いて表される.また, き裂面の相対変位は境界要素法から求めることができる. 図 14 に Type B のき裂面の相対変位 $\Delta u_{r}, \Delta u_{\theta}, \Delta u_{\phi}$ を角度毎に示寸. この図から変位 $\Delta u_{\theta}$ が他の変位に比べ非常に大き いことが分かる. $\Delta G$ に対する寄与も $\Delta u_{\theta}$ が大きいと考えられる. 図 15 に Type A, Type Cにおける相対変位 $\Delta u_{\theta}$

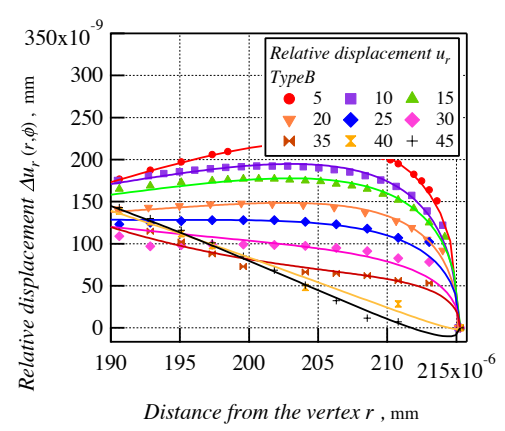

(a) $\Delta u_{r}$

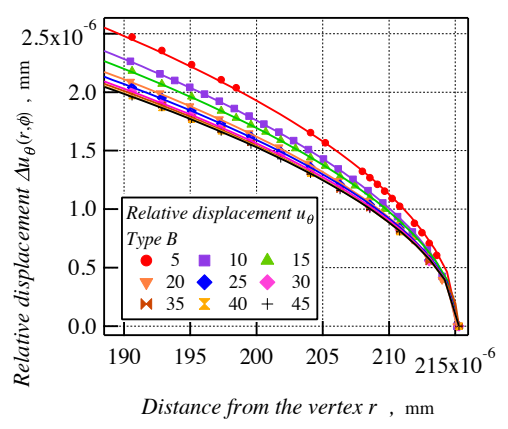

(b) $\Delta u_{\theta}$

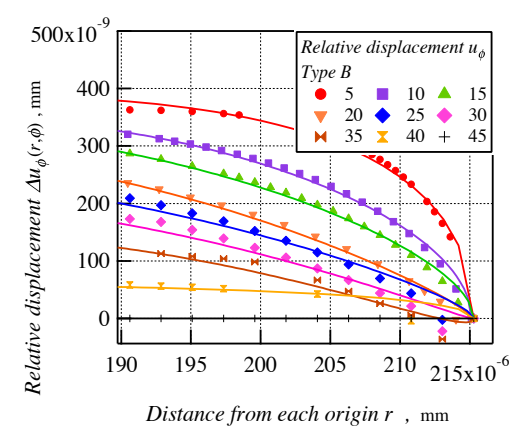

(c) $\Delta u_{\phi}$

Fig.14 Relative displacements $\Delta u_{r}, \Delta u_{\theta}, \Delta u_{\phi}$ in Type B against the distance from the vertex

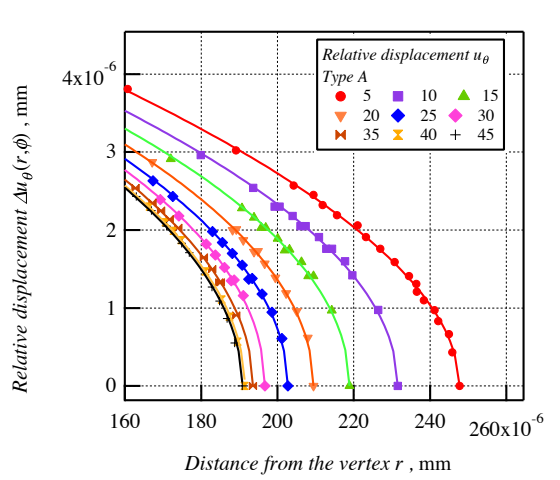

(a) Type A

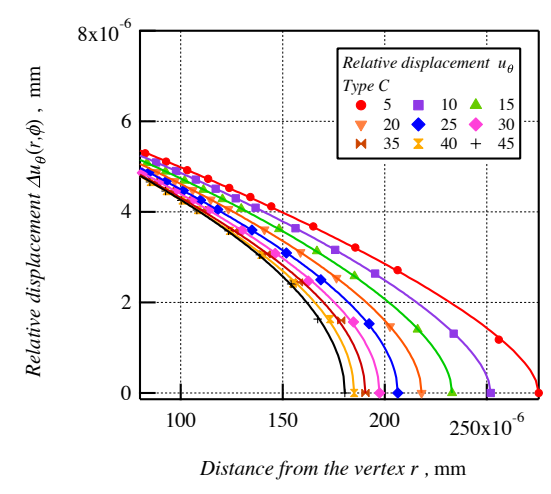

(b) Type C

Fig.15 Relative displacement $\Delta u_{\theta}$ in Type A and Type C 
を示す. 図 14 および 15 中の実線は, 最小二乗法により式(14)を用いて変位分布を近似して得られたものである.

$$
\Delta u_{j}(r, \phi)=k_{1 j}(\phi) \sqrt{a(\phi)^{2}-r^{2}}+k_{2 j}(\phi)\left\{a(\phi)^{2}-r^{2}\right\}+k_{3 j}(\phi)\{a(\phi)-r\}
$$

ここで, $j=r, \theta, \phi$ ある.

つぎに，式(5)〜(8)を式(13)に代入し，式を整理すると

$$
\begin{aligned}
& \Delta G=\int_{0}^{\frac{\pi}{2}} \int_{0}^{a(\phi)}\left\{\left(K_{1 \theta \theta} f_{1 \theta \theta} r^{1-\lambda_{\text {venex }}}+K_{2 \theta \theta} f_{2 \theta \theta} r\right) \Delta u_{\theta}(r, \phi)+\left(K_{1 r \theta} f_{1 r \theta} \theta^{1-\lambda_{\text {rentex }}}+K_{2 r \theta} f_{2 r \theta} r\right) \Delta u_{r}(r, \phi)\right. \\
& \left.+\left(K_{1 \phi \theta} f_{1 \phi \theta} r^{1-\lambda_{\text {verex }}}+K_{2 \phi \theta} f_{2 \phi \theta} r\right) \Delta u_{\phi}(r, \phi)\right\} d r d \phi
\end{aligned}
$$

が得られる. 応力は特異性を示寸が，この式で積分時には特異性を示寸項は $r^{1-\lambda_{\text {verex }}}$ となり， $1-\lambda_{\text {vertex }}>0$ で通常の 積分を行える. また，上記の式の第 1 項目の積分が行えれば，第 2 項目，第 3 項目の積分は同様にできる．そこ で，第 1 項目の積分 $\Delta G_{1}$ を示す.

$$
\begin{aligned}
& \Delta G_{1}=\int_{0}^{\frac{\pi}{2}} \int_{0}^{a(\phi)}\left(K_{1 \theta \theta} f_{1 \theta \theta} r^{1-\lambda_{\text {venex }}}+K_{2 \theta \theta} f_{2 \theta \theta} r\right) \Delta u_{\theta}(r, \phi) d r d \phi \\
& =\frac{1}{12} \int_{0}^{\frac{\pi}{2}} a^{3}\left\{\left(4 k_{1 \theta}+3 a k_{2 \theta}+2 k_{3 \theta}\right) K_{2 \theta \theta}+\frac{12 K_{1 \theta \theta} a^{-\lambda_{\text {verex }}}}{\lambda_{\text {vertex }}-2}\left(\frac{2 a k_{2 \theta}}{\lambda_{\text {vertex }}-4}+\frac{k_{3 \theta}}{\lambda_{\text {vertex }}-3}\right)\right. \\
& \left.+\frac{3 a^{-\lambda_{\text {verex }}} k_{1 \theta} K_{1 \theta \theta} \sqrt{\pi} \Gamma\left(1-\frac{\lambda_{\text {vertex }}}{2}\right)}{\Gamma\left(\frac{5}{2}-\frac{\lambda_{\text {vertex }}}{2}\right)}\right\} d \phi
\end{aligned}
$$

ここで, $k_{1 \theta}, k_{2 \theta}, k_{3 \theta}$ は角度 $\phi$ の関数である.

き裂発生に伴い解放されるエネルギ $\Delta G$ を計算した結果を表 6 に示寸，き裂が発生した時のエネルギ量が新生 き裂面に消費されるエネルギより大きくなると, き裂は成長する，き裂の生成エネルギは表面エネルギ $\omega に$ 面積 $S$ を乗じた形で表わすことができる. 寸なわち, エネルギ解放量 $\Delta U$ は

$$
\Delta U=\Delta G-2 \omega S
$$

で求められる．表面エネルギは定数，本解析ではき裂面積はすべての形状で $3.64 \times 10^{-8} \mathrm{~mm}^{2}$ であることから， $\Delta U$ の比較は $\Delta G$ により行うことができる． $\Delta G$ の大小関係は Type $\mathrm{C}>$ Type A > Type B のように得られた.

Table 6 Energy release of each crack shape

\begin{tabular}{|c|c|}
\hline Crack type & Quantity of release energy,$[\mathrm{J}]$ \\
\hline Type A & $9.02 \times 10^{-15}$ \\
\hline Type B & $7.22 \times 10^{-15}$ \\
\hline Type C & $10.1 \times 10^{-15}$ \\
\hline
\end{tabular}

\section{$5 \cdot 3$ 応力拡大係数とエネルギ解放量から見たき裂形状}

$5 \cdot 2$ の結果から，同じ面積のき裂の場合，今回調べた 3 種類のき裂では Type $\mathrm{C}$ のき裂のエネルギ解放量が大き いことが分かった. Type $\mathrm{C}$ の形状は, 角部の特異応力場の等応力線の近傍を沿うものであり, 引張り応力が大き い範囲の形状に近い.この範囲にき裂が発生した場合, その後のき裂形状を応力拡大係数の分布から判断すると, 界面内部の $\phi=45^{\circ}$ 方向にき裂は成長し，Type A に近い形状になり，若干き裂の中央部分が Type B のように湾曲す る. 一方, Type B のような場合には，側面における応力拡大係数が大きいことから，側面に沿ってき裂が成長す ることになる，その結果，Type A と Type B を合わせたような中間の形状になると考えられる。 


\section{6. 結 言}

本論文は，三次元異材接合体の界面端角部の特異応力場に微小き裂が発生した場合の応力分布およびエネルギ 解放量を三次元境界要素法により調べたものである. 本論文の結果を以下のようにまとめることができる.

（1）特異応力場内にき裂がある場合, 界面端角部を原点とした座標系で応力分布をみると, 特異応力場の応 力がき裂前縁近傍の応力場に重畳されている様子がわかる. 一方，き裂先端に座標の原点を有する円柱座標 系では，き裂の無い場合の特異応力分布がき裂先端に近い領域で，き裂を有する場合のそれより，小さくな る様子がわかる.

（2）き裂のある応力場をき裂の無い場合の応力により無次元化することで, き裂により特異応力場の応力が き裂前縁から $10^{-5} \mathrm{~mm}$ 離れた場所で比較すると 3〜4 倍大きくなっていることがわかった．また，き裂の影響 範囲は，き裂長さの 2.5〜3 倍程度であることがわかった。

（3）き裂前縁の応力拡大係数 $K_{I}$ が，き裂前縁に沿って側面に近づく（角度 $\phi$ の減少）にともない増大寸るか 減少するかは，き裂前縁と側面との交点における特異性のオーダに依存する.すなわち，特異性のオーダが 0.5 より大きいと増大し, 小さいと減少する.

（4）今回解析したき裂モデルでは，Type C のエネルギ解放量が大きく，次いで Type A, Type B と小さくな った. 応力拡大係数の分布を考慮すると初期形状が Type C の場合, Type A と Type B を合わせた中間の形状 にき裂が成長することが考えられる。

\section{文献}

Akisanya, A. R. and Fleck, N. A., Interfacial cracking from the free-edge of a long bi-material strip, International Journal of Solids and Structures, Vol.34, No. 13 (1997), pp.1645-1665.

Badrinath, V. and Henrik, M.J., Steady-state propagation of interface corner crack, International Journal of Solids and Structures, Vol.50, No.10 (2013), pp.1613-1620.

Chiu, T. and Lin, H., Analysis of stress intensity factors for three-dimensional interface crack problems in electronic packages using the virtual crack closure technique, International Journal of Fracture, Vol.156, No.1 (2009), pp.75-96.

Erdogan, F., Stress distribution in bonded dissimilar materials with cracks, Journal of Applied Mechanics, Vol.32, No.2 (1965), pp. 403-410.

Ghahremani, F. and Shih, C.F., Corner singularities of three-dimensional plane interface cracks, Journal of Applied Mechanics, Vol.59, No.1 (1992), pp.61-68.

Hutchinson, J. W. and Suo, Z., Mixed mode cracking in layered materials, Advances in Applied Mechanics, Vol.29, No.1 (1991), pp. 63-191.

井岡誠司，松田 崇，久保司郎，異種接合材料の界面端微小き裂の応力拡大係数と自由縁応力特異性の関係に関 する数值的および理論的検討, 材料, Vol.51, No.12 (2002), pp.1373-1379.

Johnson, J. and Qu, J. M., An interaction integral method for computing mixed mode stress intensity factors for curved bimaterial interface cracks in non-uniform temperature fields, Engineering Fracture Mechanics, Vol.74, No.14 (2007), pp. 2282-2291.

古口日出男, 星和久, 倉橋貴彦, 引張せん断荷重下における単純重ね合わせ継手の接着界面端角部の三次元特異 応力場に対する解析，日本機械学会論文集 A 編, 78, No.795 (2012), pp.1558-1574.

Koguchi, H. and da Costa, J. A., Analysis of the stress singularity field at a vertex in 3D-bonded structures having a slanted side surface, International Journal of Solids and Structures, Vol.47, No.22-23 (2010), pp.3131-3140.

Nagai, M., Ikeda, T. and Miyazaki, N., Stress intensity factor analysis of a three-dimensional interface crack between dissimilar anisotropic materials, Engineering Fracture Mechanics, Vol.74, No.16 (2007), pp.2481-2497.

Nakamura, T., Three-dimensional stress fields of elastic interface cracks, Journal of Applied Mechanics, Vol.58, No.4 (1991), pp. 939-946.

Nakamura, T. and Parks, D. M., Three-dimensional stress field near the crack front of a thin elastic plate, Journal of Applied Mechanics, Vol.55, No.4 (1988), pp.805-813.

Nahta, R. and Moran, B., Domain integrals for axisymmetric interface crack problems, International Journal of Solids and Structures, Vol.30, No.15 (1993), pp. 2027-2040.

Nomura, Y., Ikeda, T. and Miyazaki, N., Stress intensity factor analysis at an interfacial corner between anisotropic bimaterials under thermal stress, Engineering Fracture Mechanics, Vol.76, No.2 (2009), pp.221-235. 
Rice, J. R. and Sih, G. C., Plane problems of cracks in dissimilar media, Journal of Applied Mechanics, Vol.32, No.2 (1965), pp. 418-423.

Rice, J. R., Elastic fracture mechanics concepts for interfacial cracks, Journal of Applied Mechanics, Vol.55, No.1 (1988), pp. 98-103.

Sukumar, N., Huang, Z. Y., Pre' vost, J. H. and Suo, Z., Partition of unity enrichment for bimaterial interface cracks, International Journal of Numerical Methods in Engineering, Vol.59, No.8 (2004), pp. 1075-1102.

Tvergaard, V. and Hutchingson, J.W., Mode III effects on interface delimitation, Journal of the Mechanics and Physics of Solids, Vol.56, No.1 (2008), pp.215-229.

Williams, M. L., The stresses around a fault or crack in dissimilar media, Bullettin of the Seismological Society of America, Vol.49, No.2 (1959), pp. 199-204.

Yuuki, R. and Cho, S. B., Efficient boundary element analysis of stress intensity factors for interface cracks in dissimilar materials, Engineering Fracture Mechanics, Vol.34, No.1 (1989), pp. 179-188.

結城良治編集, 界面の力学, 培風館(1993), pp.85-124.

\section{References}

Akisanya, A. R. and Fleck, N. A., Interfacial cracking from the free-edge of a long bi-material strip, International Journal of Solids and Structures, Vol.34, No. 13 (1997), pp.1645-1665.

Badrinath, V. and Henrik, M.J., Steady-state propagation of interface corner crack, International Journal of Solids and Structures, Vol.50, No.10 (2013), pp.1613-1620.

Chiu, T. and Lin, H., Analysis of stress intensity factors for three-dimensional interface crack problems in electronic packages using the virtual crack closure technique, International Journal of Fracture, Vol.156, No.1 (2009), pp.75-96.

Erdogan, F., Stress distribution in bonded dissimilar materials with cracks, Journal of Applied Mechanics, Vol.32, No.2 (1965), pp. 403-410.

Ghahremani, F. and Shih, C.F., Corner singularities of three-dimensional plane interface cracks, Journal of Applied Mechanics, Vol.59, No.1 (1992), pp.61-68.

Hutchinson, J. W. and Suo, Z., Mixed mode cracking in layered materials, Advances in Applied Mechanics, Vol.29, No.1 (1991), pp. 63-191.

Ioka, S., Matsuda, T. and Kubo, S., A numerical and theoretical study on relationship between stress intensity factor of a small edge crack on interface and free-edge stress singularity of bonded dissimilar materials, Zairyo, Vol.51, No.12 (2002), pp.1373-1379 (in Japanese).

Johnson, J. and Qu, J. M., An interaction integral method for computing mixed mode stress intensity factors for curved bimaterial interface cracks in non-uniform temperature fields, Engineering Fracture Mechanics, Vol.74, No.14 (2007), pp. $2282-2291$.

Koguchi, H., Hoshi, K. and Kurahashi, T., Analysis for three-dimensional singular stress field at a vertex of bonded interface edge in single lap joint under tensile-shear load, Transactions of the Japan Society of Mechanical Engineers, Series A, Vol.78, No.795 (2012), pp.1558-1574 (in Japanese).

Koguchi, H. and da Costa, J. A., Analysis of the stress singularity field at a vertex in 3D-bonded structures having a slanted side surface, International Journal of Solids and Structures, Vol.47, No.22-23 (2010), pp.3131-3140.

Nagai, M., Ikeda, T. and Miyazaki, N., Stress intensity factor analysis of a three-dimensional interface crack between dissimilar anisotropic materials, Engineering Fracture Mechanics, Vol.74, No.16 (2007), pp.2481-2497.

Nakamura, T., Three-dimensional stress fields of elastic interface cracks, Journal of Applied Mechanics, Vol.58, No.4 (1991), pp. 939-946.

Nakamura, T. and Parks, D. M., Three-dimensional stress field near the crack front of a thin elastic plate, Journal of Applied Mechanics, Vol.55, No.4 (1988), pp.805-813.

Nahta, R. and Moran, B., Domain integrals for axisymmetric interface crack problems, International Journal of Solids and Structures, Vol.30, No.15 (1993), pp. 2027-2040.

Nomura, Y., Ikeda, T. and Miyazaki, N., Stress intensity factor analysis at an interfacial corner between anisotropic bimaterials under thermal stress, Engineering Fracture Mechanics, Vol.76, No.2 (2009), pp.221-235.

Rice, J. R. and Sih, G. C., Plane problems of cracks in dissimilar media, Journal of Applied Mechanics, Vol.32, No.2 (1965), pp. $418-423$.

Rice, J. R., Elastic fracture mechanics concepts for interfacial cracks, Journal of Applied Mechanics, Vol.55, No.1 (1988), pp. 
98-103.

Sukumar, N., Huang, Z. Y., Pré vost, J. H. and Suo, Z., Partition of unity enrichment for bimaterial interface cracks, International Journal of Numerical Methods in Engineering, Vol.59, No.8 (2004), pp. 1075-1102.

Tvergaard, V. and Hutchingson, J.W., Mode III effects on interface delimitation, Journal of the Mechanics and Physics of Solids, Vol.56, No.1 (2008), pp.215-229.

Williams, M. L., The stresses around a fault or crack in dissimilar media, Bullettin of the Seismological Society of America, Vol.49, No.2 (1959), pp. 199-204.

Yuuki, R. and Cho, S. B., Efficient boundary element analysis of stress intensity factors for interface cracks in dissimilar materials, Engineering Fracture Mechanics, Vol.34, No.1 (1989), pp. 179-188.

Yuuki, R. ed., Interface mechanics, Baifukan (1993), pp.85-124 (in Japanese). 